\title{
The Analysis of the Influence Factors of China's Outbound Tourism Market
}

He Liua

Shanghai University, Management, 200444, Shanghai, China

\begin{abstract}
Outbound tourism gets special attention from tourism academic circles and tourism companies recently. And now China has become the world's largest outbound tourism consumer. So this paper is written to research the influence factors of China's outbound tourism market, providing reference for the study of China's outbound tourism market. The literature study have found that the number of China's outbound tourism related to the duration of their leisure trips, exchange rate, residents' deposits and the number of tourism agency. By using of the econometric methods and R-studio, we build a multiple linear regression model. In the end, we get a conclusion by quantitative analysis of data and qualitative analysis of tourism's law. We found that there are linear relations exists in logarithm of the number of China's outbound tourism, the residents' deposits , the logarithm of duration of their leisure trips and the logarithm of number of tourism agency.
\end{abstract}

\section{Introduction}

China's tourism development is very different from that of foreign countries. Foreign tourism is the result of market development, while China's tourism industry has obvious characteristics of political diplomacy at the beginning. The tourism administration and tourism services are mainly aimed at inbound visitors who have a high political status ${ }^{[1]}$ 。 Since the reform and opening up in the china, the social economy has made great progress, and the political attribute of China's tourism industry has been weakened gradually. In recent years, with the development and progress of social economy, the improvement of people's living standard and the improvement of service facilities, the tourism industry has achieved real and substantial development ${ }^{[2]}$.

People need two basic conditions to travel. The one is a certain amount of flowing capital, the other is enough free time ${ }^{[3]}$. Especially, and the outbound travel is more demanding in terms of the quality of money and free time. In addition, the realization of outbound tourism should also have a certain amount of tourism experience and convenient tourism suppliers. China has been rated as the world's largest source of outbound tourists for many years

\section{Literature research}

In the reason of outbound tourism, professor Vera Shanshan Lin believe that compared with staying in China, the income level and cost of staying are two important factors influencing Chinese residents' traveling abroad [3]. Tony s. m. Tse and j. s. Perry Hobson studied China's outbound tourism through analyzing the macro-environment and found that social, economic and political factors had a significant impact ${ }^{[4]}$. According to the domestic tourism demand prospects, Wei Xiaoan and Feng Zengsu think that economic factors have a significant impact on tourists' choice of travel scope. Per capita GNP above $\$ 1000$ will make people have international tourism motivation ${ }^{[5]}$.

In terms of influencing factors of outbound tourism, most studies use outbound tourists as a measure of outbound tourism scale. Deng Aiming found that the number of China's outbound tourists has a long-term equilibrium relationship with income levels and real exchange rates by analyzing of China's tourism sample data from 1993 to $2010^{[6]}$. Professor $\mathrm{Wu}$ believes that outbound tourism is closely related to the exchange rate ${ }^{[7]}$ Tong Yuquan takes the total number of Chinese outbound tourists as the explained variable, and per capita GDP, per capita net income of rural residents, per capita disposable income of urban residents, urbanization rate, exchange rate and Engel coefficient of urban households were selected as explanatory variables. Finally he found that Per capita GDP is the leading factor in determining outbound tourism ${ }^{[8]}$. Du Jiang and Dai Bing thought that there are seven factors have a significant impact on the outbound tourism market. They are economic factors, political and diplomatic factors, air transport, macro-regulation and micro-regulation, destination

a Corresponding author: 1013999035@qq.com 
security, promotional activities and social culture ${ }^{[9]}$.

\section{Study design}

\subsection{Data source and variable Settings}

Firstly outbound tourism should meet the necessary conditions for tourism, enough funds and sufficient free time. Free time is related to social development and individual choice. It is different from the holiday and unable to be counted efficiently; at the macro level, household savings can reflect the financial strength of residents from the side; outbound tourism is a special kind of trade import, involving economic exchanges. So it is necessary to research the effect of exchange rate; the language barrier is very obvious for outbound tourism. In order to get a better travel experience, we need to resort to the help of tourism service agencies. Generally speaking, the more days of people spending on outbound tourism, the fewer tourists.so we take the outbound travel days into research.

Based on the above study, five variables are selected in this paper. They are the number of outbound tourists from 2007 to 2015, the exchange rate of RMB, the amount of resident deposits, the number of travel agencies and travel days. The exchange rate and resident deposits can be getting from the official website of national bureau of statistics. The number of tourists and the agencies can be known from the statistical bulletin of national tourism administration. And the days can be getting from the reports and literature. table 1 is for specific data:

Table 1. Data summary.

\begin{tabular}{|c|c|c|c|c|c|}
\hline Year & $\begin{array}{c}\text { The number } \\
\text { of outbound } \\
\text { tourists }\end{array}$ & $\begin{array}{c}\text { Exchange } \\
\text { rate }\end{array}$ & $\begin{array}{c}\text { Resident } \\
\text { deposits } \\
\text { (yuan) }\end{array}$ & $\begin{array}{c}\text { The } \\
\text { number of } \\
\text { agencies }\end{array}$ & $\begin{array}{c}\text { Travel } \\
\text { days }\end{array}$ \\
\hline 2007 & 4095.4 & 7.604 & 172534.2 & 18943 & 2.1 \\
\hline 2008 & 4584.44 & 6.9451 & 217885.4 & 20110 & 2.4 \\
\hline 2009 & 4765.63 & 6.831 & 260771.7 & 20399 & 3.2 \\
\hline 2010 & 5738.65 & 6.7695 & 303302.5 & 22784 & 4 \\
\hline 2011 & 7025 & 6.4588 & 343635.9 & 23690 & 4.2 \\
\hline 2012 & 8318.27 & 6.3125 & 399551 & 24944 & 4.3 \\
\hline 2013 & 9818.52 & 6.1932 & 447601.6 & 26054 & 4.9 \\
\hline 2014 & 10700 & 6.2166 & 485261.3 & 26650 & 5.1 \\
\hline 2015 & 11700 & 6.2284 & 526508.5 & 27621 & 5.3 \\
\hline
\end{tabular}

Table 2. The definition of variables.

\begin{tabular}{|c|c|c|}
\hline Symbol & Measuring way & Meaning \\
\hline Y & $\begin{array}{c}\text { Take the logarithm of the number } \\
\text { of outbound tourists }\end{array}$ & Explained variable \\
\hline X1 & $\begin{array}{c}\text { Take the logarithm of exchange } \\
\text { rate }\end{array}$ & Monetary conditions \\
\hline X2 & $\begin{array}{c}\text { Take the logarithm of number of } \\
\text { agencies }\end{array}$ & $\begin{array}{c}\text { Ease of access to } \\
\text { information }\end{array}$ \\
\hline X3 & the amount of resident deposits & Economic strength \\
\hline X4 & Take the logarithm of travel days & Time cost \\
\hline
\end{tabular}

\subsection{Research models and assumptions}

In this paper, the following equation is constructed by using the multiple linear regression model and combining the economic theory with the operation law of tourism:

$$
Y=\beta_{0}+\beta_{1} X_{1}+\beta_{2} X_{2}+\beta_{3} X_{3}+\beta_{4} X_{4}
$$

Among them, " $\beta$ " is the coefficient.

Based on the above analysis, the following hypotheses are proposed:

(1) The lower the exchange rate, the less people travel abroad

(2) The more total household savings, the more people travel abroad

(3) The more travel agencies, the more people travel abroad

(4) The longer the days of outbound travel, the less people travel abroad

\section{Empirical test}

This paper uses R-studio software for data analysis. The detailed analysis steps are shown below.

\subsection{Stationary test}

This paper has time series data. Classical regression analysis has an important hypothesis. It is that the data is stable.

\subsubsection{Graphic test of stability}

Figure 1 is the result:

It can be seen from the figure that the time series data is non-stationary.
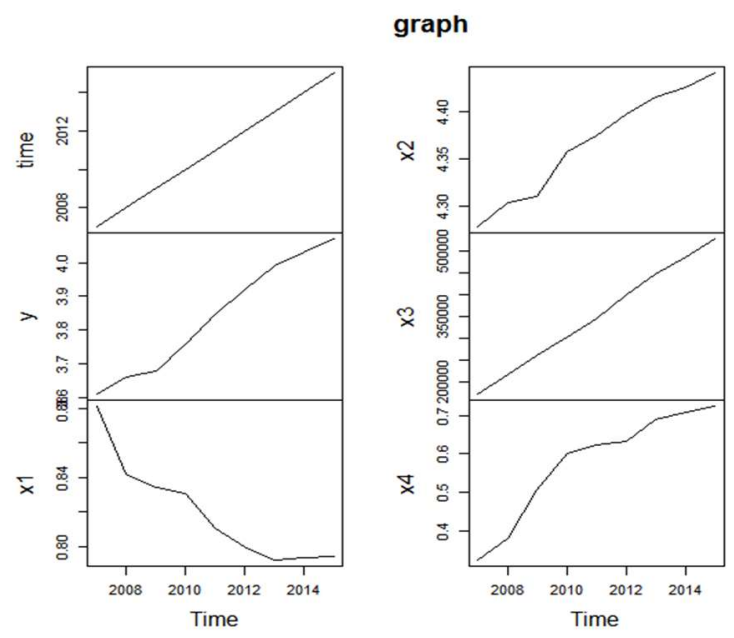

Figure 1. Test of stability.

\subsubsection{Unit root test for stability}

Table 3 is the result:

Table 3. Unit root test.

\begin{tabular}{|c|c|c|c|c|}
\hline $\begin{array}{c}\text { The } \\
\text { independent } \\
\text { variables }\end{array}$ & $\mathrm{X}_{1}$ & $\mathrm{X}_{2}$ & $\mathrm{X}_{3}$ & $\mathrm{X}_{4}$ \\
\hline $\mathrm{t}$ & 0.007557 & 0.001866 & 0.0001758 & 0.0118 \\
\hline
\end{tabular}


We can found that $t<0.05$, so the data does not have a unit root.

\subsubsection{Co-integration test}

Co-integration means that there is a common trend of randomness. It is aimed to determine whether a set of linear combinations of nonstationary sequences have stable equilibrium relations. The result is below:

Table 4. Co-integration test.

\begin{tabular}{|c|c|c|}
\hline DF & $\mathrm{t}$ & $\mathrm{n}$ \\
\hline-4.0347 & 0.0014 & 0.1135 \\
\hline
\end{tabular}

Because that $t<0.05$, the data in this paper has stationarity and can be analyzed by regression.

\subsection{Variable correlation analysis}

Pearson's coefficient can accurately reflect the degree of correlation between two variables. It is represented by $r$ and describes the degree of linear correlation between two variables. The greater the absolute value of $r$, the stronger the correlation. Table 5 shows the result.

Table 5. Correlation analysis.

\begin{tabular}{|c|c|c|c|c|}
\hline $\begin{array}{c}\text { Independent } \\
\text { variable }\end{array}$ & $\mathrm{X}_{1}$ & $\mathrm{X}_{2}$ & $\mathrm{X}_{3}$ & $\mathrm{X}_{4}$ \\
\hline $\mathrm{r}$ & -0.9227 & 0.989502 & 0.993557 & 0.928283 \\
\hline
\end{tabular}

All correlation coefficients(r) are between 0.70 and 0.99 . So these variables are highly correlated with the number of outbound tourists.

\subsection{Establishment of multiple regression model}

Multiple linear regression models can be established by regression analysis:

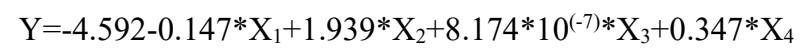

\subsubsection{Test of goodness of fit}

Index $\mathrm{R}^{2}$ can describe the fitting degree of multiple linear regression equation and data. $R^{2}=S$ 回 $/ S$ 总

The larger index is, the better the fitting degree of the model is.

\subsubsection{Significance test of equation ( $F$ test)}

The index $\mathrm{F}$ can be used to indicate whether the linear relationship between the depended and all independent variables is significant in general.

\subsubsection{Significance test of variables (t test)}

We can see the influence degree of each independent variable on the dependent variable by this test. If the effect is not significant, it should be eliminated.

\subsubsection{DW test}

Because sequence autocorrelation has a great influence on the rationality of multiple linear regression models, we use DW test to determine whether there is sequence autocorrelation between each independent variable. In practical problems, when the value of DW statistic is around 2 , it can be concluded that the regression model is effective.

\subsubsection{Test results statistics}

Table 6. The test result.

\begin{tabular}{|c|c|c|c|}
\hline Parameter & $\mathrm{R}^{2}$ & $\mathrm{~F}$ & $\mathrm{DW}$ \\
\hline Result & 0.991 & 231 & 2.402 \\
\hline
\end{tabular}

Table 7. T test.

\begin{tabular}{|c|c|}
\hline Variable & $\mathrm{t}$ \\
\hline Intercept & -1.397 \\
\hline $\mathrm{X} 1$ & -0.239 \\
\hline $\mathrm{X} 2$ & 2.58 \\
\hline $\mathrm{X} 3$ & 2.803 \\
\hline $\mathrm{X} 4$ & -2.171 \\
\hline
\end{tabular}

Table 6 shows that $\mathrm{R}^{2}>95 \%$, so multivariate linear equations fit well. Next we can find that $\mathrm{F}(4,5)=6.256$ with $95 \%$ confidence and $\mathrm{F}>\mathrm{F}(4,5)$, so in general, the independent variables of the equation have a significant influence on the dependent variables. The value of DW is close to 2 , indicating that there is no sequence correlation in the regression model.

We can know that when $\mathrm{a}=0.1, \mathrm{t} 2 / \mathrm{a}(5)=2.015$. Table 7 shows the $t$ value of $X_{1}$ is less than 2.015. So the effect of $\mathrm{X}_{1}$ is not significant.

\subsubsection{Heteroscedasticity test}

If the linear regression model has heteroscedasticity, then the regression equation cannot be established. The paper use Breusch-Pagan to test. Table 8 is the result:

Table 8. Heteroscedasticity test.

\begin{tabular}{|c|c|c|}
\hline BP & df & p-value \\
\hline 3.524 & 4 & 0.4742 \\
\hline
\end{tabular}

$\mathrm{P}>0.05$, so there is no heteroscedasticity in the regression model with $95 \%$ confidence.

\subsection{Model optimization}

In order to remove the independent variables with insignificant effects, the backward stepwise regression method is used to optimize model. The stop-judgment criterion is the exact AIC criterion.

Table 9 is the result: 
Table 9. Stepwise regression result.

\begin{tabular}{|c|c|c|c|c|c|c|}
\hline Variable & & $\begin{array}{c}\text { Remove } \\
\mathrm{X}_{1}\end{array}$ & None & $\begin{array}{c}\text { Remove } \\
\mathrm{X}_{2}\end{array}$ & $\begin{array}{c}\text { Remove } \\
\mathrm{X}_{3}\end{array}$ & $\begin{array}{c}\text { Remove } \\
\mathrm{X}_{4}\end{array}$ \\
\hline First & AIC & -73.736 & -71.863 & -65.046 & -64.086 & -66.857 \\
\hline Second & AIC & & -73.736 & -66.655 & -66.022 & -68.333 \\
\hline
\end{tabular}

The AIC in $<$ none $>$ is the result when no variables are deleted. When remove the $\mathrm{X}_{1}$, the AIC decreased. But if remove other variables, the AIC would increase. So remove the $X_{1}$.

The revised regression equation is below:

$$
\mathrm{Y}=-4.856+1.969 * \mathrm{X}_{2}+8.186 * 10^{-7} * \mathrm{X}_{3}-0.331 * \mathrm{X}_{4}
$$

\subsection{Optimization model test}

Table 10. Optimization model test.

\begin{tabular}{|c|c|c|c|c|}
\hline Parameter & $\mathrm{R}^{2}$ & $\mathrm{~F}$ & $\mathrm{DW}$ & $\mathrm{p}$ \\
\hline Result & 0.993 & 379.5 & 2.38 & $2.57 * 10^{-6}$ \\
\hline
\end{tabular}

Table 11. T test of optimization model.

\begin{tabular}{|c|c|c|c|c|}
\hline & Intercept & $\mathrm{X}_{2}$ & $\mathrm{X}_{3}$ & $\mathrm{X}_{4}$ \\
\hline $\mathrm{t}$ & -1.742 & 2.952 & $\begin{array}{c}3.11 \\
7\end{array}$ & -2.526 \\
\hline $\mathrm{p}$ & & 0.03 & 0.02 & 0.05 \\
\hline
\end{tabular}

The result showed that both $\mathrm{R}^{2}$ and $\mathrm{F}$ are greater than the original. The number of DW is also closer to 2 . So the new model has a better fit.

\subsection{Results analysis}

The final multiple linear regression model is:

$$
\mathrm{Y}=-4.856+1.969 * \mathrm{X}_{2}+8.186 * 10^{-7} * \mathrm{X}_{3}-0.331 * \mathrm{X}_{4}
$$

We can find that there are linear relations exists in logarithm of the number of China's outbound tourism, the residents' deposits, the logarithm of duration of their leisure trips and the logarithm of number of tourism agency. And there is no linear correlation between the total number of outbound tourists and the exchange rate. From the perspective of economic theory, the exchange rate is lower and the number of outbound tourists is decreased. According to experts, from the perspective of clients' consultation and reservation, exchange rate is not the primary consideration in tourism decision-making. Most tourists go abroad only once or twice a year, or just for the first time. Their travel plans are usually completed two months in advance and they will not change their plans easily due to exchange rate fluctuations. Therefore, exchange rate fluctuations have had little impact on the number of outbound tourists in recent years ${ }^{[10]}$.

\section{Conclusion}

This paper studies the influencing factors of outbound tourism by means of econometrics and the development law of tourism industry. There is a positive correlation between the logarithm of outbound tourists and the logarithm of number of travel agencies. There is a positive correlation between logarithm of outbound tourists and the total amount of resident deposits. There is a negative correlation between the logarithm of outbound tourists and the logarithm of travel days. China's booming outbound tourism market owes much to the country's rapid economic growth, including rising living standards and disposable income. Secondly, the increase in the number of travel agencies provides much convenient information for outbound tourists. Finally, the improvement of traffic conditions and the convenience of visa and others have saved the time and cost of outbound tourists and promoted the continuous prosperity of China's outbound tourism market.

So in the future, firstly the government should ensure the healthy and stable development of the outbound tourism market. Secondly, it is necessary to develop inbound tourism while properly guiding citizens to travel abroad. Finally, it is important to insist the supply-side structural reform proposed in the 13th five-year plan of china. And promote the balance between supply and demand and the transformation and upgrading of the tourism industry.

\section{References}

1. Wu Zhongcai. Quantitative research on the effect of inbound tourism on economic growth [J]. Journal of Beijing International Studies University, vol.9, pp.30-33, 2007.

2. Li Wenxing, Xu Changsheng and Ai Chunrong. Population age structure and household consumption in China: 1989-2004 [J]. Economic Research Journal, vol.7. pp.118-129, 2008.

3. Vera Shanshan Lin, Anyu Liu and Haiyan Song, Modeling and Forecasting Chinese Outbound Tourism: An Econometric Approach [J]. Journal of Travel \& Tourism Marketing, vol.32, pp.34-49, 2015.

4. Tony S. M. Tse and J. S. Perry Hobson, The Forces Shaping China's Outbound Tourism [J]. Journal of China Tourism Research, vol.4. pp.136-155, 2008.

5. Wei Xiaoan, Feng Zongsu. China's tourism industry: industrial policy and coordinated development [M]. Bei Jing: Tourism education press, 1993.

6. Deng Aiming. Empirical research on the determinants of Chinese outbound tourism demand [J]. Macroeconomics, vol.12, pp.79-83, 2011.

7. Wu Chunyou, Xie Fengyuan and Quan Hua. An empirical study on the relationship between tourism development and China's economic growth [J]. Science-Technology and Management, vol.11, pp.8-11, 2009.

8. Tong Yuquan. The gradual regression analysis of the influencing factors of China's outbound tourism market [J]. Market Forum, vol.10, pp.70-72, 2009.

9. Du Jiang and Dai Bing. Annual report on China's outbound tourism development [M]. Bei Jing: Tourism education press, 2008. 
10. Zhang Chengsi. Inflation, economic growth and money supply: a return to monetarism? [J]. The Journal of World Economy, Vol.8.pp.3-21, 2012. 